\title{
The Role of Wine in Modulating Inflammatory Processes: A Review
}

\author{
Chiara Di Lorenzo ${ }^{1, *(1)}$, Creina Stockley ${ }^{2}$, Francesca Colombo ${ }^{1}$, Simone Biella ${ }^{1}$, \\ Francesca Orgiu ${ }^{1}$, Mario Dell'Agli ${ }^{1}$ (1) and Patrizia Restani ${ }^{1}$ \\ 1 Department of Pharmacological and Biomolecular Sciences, Università degli Studi di Milano, via Balzaretti \\ 9, 20133 Milan, Italy; francesca.colmbo1@unimi.it (F.C.); simone.biella@unimi.it (S.B.); \\ francesca.orgiu@unimi.it (F.O.); mario.dellagli@unimi.it (M.D.); patrizia.restani@unimi.it (P.R.) \\ 2 The Australian Wine Research Institute, Glen Osmond, SA 5064, Australia; creina.stockley@awri.com.au \\ * Correspondence: chiara.dilorenzo@unimi.it; Tel.: +39-02-5031-8274
}

Received: 22 October 2018; Accepted: 9 November 2018; Published: 15 November 2018

\begin{abstract}
Several epidemiological studies associated the consumption of wine with the reduction of the risk factors for cardiovascular disease and certain cancers, as well as for diabetes. These conditions are characterized by inflammatory mechanisms in addition to other biological mechanisms. Acute and chronic inflammation is mediated by a plethora of biomarkers production and pathway activation. Since the health promoting properties of wine in different pathological conditions may include the reduction of inflammation, the aim of this paper was to collect and review the in vitro, in vivo, and human studies performed to evaluate the effects of wine on different models of inflammation. Although great variability in wine intake, period of consumption, and content of phenolic compounds was observed, data from both human and animal studies showed a positive modulation of inflammatory biomarkers (cytokines, coagulation parameters) and oxidative stress (mainly malondialdehyde) involved in cardiovascular function. In addition, some convincing evidence was obtained in different models suggesting a positive modulation of risk factors for gastric and intestinal inflammation. Contradictory results were obtained for metabolic syndrome and type 2 diabetes. To date, no significant paper has been published in the area of immune function. Integrating in vivo data and in vitro studies, the NF-KB pathway has been identified as a critical target for the protective properties of a moderate wine consumption.
\end{abstract}

Keywords: wine; inflammation; in vitro methods; animal studies; human trials

\section{Introduction}

The interest in a positive role of wine on human health has grown since 1979, when a first report showing an inverse association between moderate wine consumption and mortality was published [1]. This correlation has been confirmed by epidemiological observations; in particular, the lower cardiovascular mortality rate in France in comparison with other countries where a similar consumption of saturated fats was reported, the so-called "French paradox" [2]. Since then, many authors have associated the consumption of wine with a J-shaped reduction of the risk factors for cardiovascular disease and certain cancers, as well as for diabetes and dementia [3,4]. Although different factors are involved (age, phenotypes, dietetic habits, etc.), the observed beneficial effects of red wine in particular, are generally associated with the moderate consumption, which could be defined as consumption of 200-300 mL/day for men (corresponding to 20-30 g ethanol) and 100-200 mL/day for women (10-20 g ethanol) with meals [5,6].

Most scientific studies have suggested that any positive effects of wine on human health are associated with its phenolic compounds and ethanol, that can synergistically affect several biochemical factors with potential cardioprotective properties, including lipid profile, platelet aggregation, 
and endothelial function. In more detail, flavonoids and their metabolites, which are the most important phenolic fractions for human health, are generally responsible for the antioxidant and radical scavenging activity of wine. Red wine contains flavanols (500-1500 mg/L), flavonols (50-200 mg/L), and anthocyanins (90-400 mg/L) [7]. In addition, a non-flavonoid phenolic compound has been extensively studied for its healthy potential: the stilbene monomer trans-resveratrol $[8,9]$. According to some authors, the mechanism associated with the beneficial effects of wine could be due not only to phenolic compounds but also to an increase of uric acid concentration in plasma, and of its related antioxidant activity [10]. If oxidative stress is recognized as one of the main factors in promoting different pathological conditions, an increasing body of evidence shows that several chronic diseases are modulated by inflammation; among others: arthritis, cancer, cardiovascular diseases, diabetes, chronic inflammatory bowel diseases (IBD), and neurological diseases [11]. The dysregulation of various signaling pathways, such as the nuclear factor kappa-B (NF- $\mathrm{B})$ and signal transducer and activator of transcription 3 (STAT3), seems to be involved in inflammation. In fact, these factors regulate the transcription of specific enzymes, such as cycloxigenase-2 (COX-2), matrix metalloproteinase-9 (MMP-9), and inflammatory cytokines (tumor necrosis factor alpha (TNF- $\alpha$ ), interleukin-1, -6, -8, (IL-1, IL-6, IL-8), and chemokines) [12]. The relationship between inflammation and chronic diseases has been suggested by different papers [11,13], as well as the possible positive role of wine in this process by in vitro and in vivo models. The results of these studies are often contradictory due to: (1) differences in the experimental model used; (2) heterogeneous biomarkers considered, since inflammation is a complex phenomenon, which can affect several physiological systems and pathways; (3) difficulty in selecting reliable biomarkers to measure the positive effects; and (4) the absence of the chemical characterization of wine, where several molecules (including alcohol) can be responsible for the increase or reduction of inflammatory biomarkers.

On the basis of the limits reported above, the aim of this paper was the collection and critical assessment of data present in the scientific literature, where inflammation was correlated with the intake of wine. In vitro and in vivo models as well as human trials will be considered, in order to identify the most suitable inflammatory biomarkers, and the most useful models/methods for the quantification of these biomarkers and their variations from moderate wine consumption.

\section{Methods}

The following databases were searched electronically to identify relevant articles published from database inception up to September 2018: PubMed/Medline, Embase, Cab Abstract. The search limits were in vitro, in vivo, clinical methodologies, and the European languages. A search strategy was developed for each database. using specific medical subject heading (MeSH) terms (e.g., inflammation mediators, inflammatory diseases, and wine) in addition to relevant text keywords (alcohol, wine, methods, analytical approaches).

Titles and abstracts of collected citations were first screened to identify the suitable publications, that is in vivo methods developed in humans or animals, and in vitro approaches used to evaluate the effect of wine/wine extracts in inflammatory pathways. Papers reporting data on the use of pure standard compounds, reviews, and patents were excluded.

\section{Results and Discussion}

The search by title and abstract retrieved 424 papers. After removal of duplicates and application of the inclusion/exclusion criteria, the total number of papers was 27.

\subsection{In Vitro Methods}

Table 1 reports the in vitro methods applied to investigate the effects of wine on parameters related to inflammation. Intestinal inflammation was the most common condition investigated, using Caco-2 and HT29 cells. Both are well characterized epithelial cell lines, derived from a primary colon tumor; thanks to their similarities with enterocytes of the human small intestine, they are a suitable model to study effects/absorption of food substances [12-15]. 
Table 1. Selected papers describing in vitro trials describing the wine effects on inflammation.

\begin{tabular}{|c|c|c|c|c|c|c|}
\hline Wine/Dosage & Model & Aim & Biomarkers & Method & $\begin{array}{l}\text { Outcomes Showing Statistical } \\
\text { Significant Changes }\end{array}$ & Ref. \\
\hline \multicolumn{7}{|l|}{ Endothelial function } \\
\hline 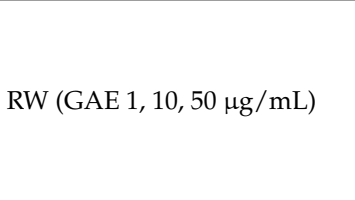 & $\begin{array}{l}\text { HUVEC } \\
\text { HMEC }\end{array}$ & $\begin{array}{l}\text { To evaluate the vascular anti-inflammatory effects } \\
\text { of two typical South Italy RWE (Primitivo and } \\
\text { Negroamaro) and the specific contribution of } \\
\text { each polyphenol }\end{array}$ & $\begin{array}{l}\text { ICAM-1, VCAM-1 and E-Selectin, } \\
\text { MCP-1, M-CSF, NF- } \mathrm{B} \text {, } \\
\text { AP-1, Endothelial-monocyte adhesion }\end{array}$ & $\begin{array}{l}\text { PCR } \\
\text { ELISA }\end{array}$ & $\begin{array}{l}\text { Both RW down-regulated the } \\
\text { expression of adhesion molecules, } \\
\text { ICAM-1, VCAM-1, E-Selectin, MCP-1, } \\
\text { and M-CSF. The results were } \\
\text { statistically significant starting from } \\
\text { the lowest concentration }(1 \mu \mathrm{g} / \mathrm{mL})\end{array}$ & {$[14]$} \\
\hline \multicolumn{7}{|l|}{ Gastric/intestinal function } \\
\hline RW and DRW (GAE $50 \mu \mathrm{M})$ & Caco-2 & $\begin{array}{l}\text { To assess the effects of wine on intestinal } \\
\text { inflammation }\end{array}$ & IL-6, IL-8, ICAM, COX 2 & $\begin{array}{l}\text { ELISA } \\
\text { PCR }\end{array}$ & $\begin{array}{l}\text { Only IL-6 was significantly reduced by } \\
\text { RW and DRW }(p<0.05)\end{array}$ & [15] \\
\hline $\begin{array}{l}\text { PPE from RWE }(200,400 \text {, } \\
\text { and } 600 \mu \mathrm{g} / \mathrm{mL})\end{array}$ & HT-29 & $\begin{array}{l}\text { To evaluate the potential anti-inflammatory action } \\
\text { of RWE enriched in anthocyanins }(25.9 \mathrm{mg} / \mathrm{g})\end{array}$ & IL-8, COX-2, NF-кB & ELISA & $\begin{array}{l}\text { RWE reduced NF-kB, IL-8 and COX-2 } \\
\text { production in a } \\
\text { concentration-dependent manner }\end{array}$ & [16] \\
\hline $\begin{array}{l}\text { PPE from RWE }(200,400 \text {, } \\
\text { and } 600 \mu \mathrm{g} / \mathrm{mL})\end{array}$ & HT-29 & $\begin{array}{l}\text { To elucidate molecular mechanisms underlying } \\
\text { the anti-inflammatory action of a PPE from } \\
\text { Portuguese RWE }\end{array}$ & JAK/STAT and Nrf2 pathways & PCR & $\begin{array}{l}\text { RWE significantly reduced the nuclear } \\
\text { levels of phosphorylated STAT1 and } \\
\text { the cellular levels of phosphorylated } \\
\text { JAK1 induced by cytokines, } \\
\text { suppressing the JAK/STAT } \\
\text { inflammatory signaling cascade }\end{array}$ & {$[17]$} \\
\hline $\begin{array}{l}\text { RWE Port Barrel Reserve } \\
\text { prepared from LeNoir grapes } \\
\text { (Vitis aestivalis hybrid) } \\
\text { assayed at } 25-100 \mu \mathrm{g} / \mathrm{mL}\end{array}$ & $\begin{array}{l}\text { Human } \\
\text { colon-derived } \\
\text { CCD-18Co } \\
\text { myofibroblasts } \\
\text { cells }\end{array}$ & $\begin{array}{l}\text { To assess the chemopreventive potential of } \\
\text { polyphenolics vs. the inflammation induced by } \\
\text { external stimuli in human colon-derived } \\
\text { CCD-18Co myofibroblasts cells. To assess the } \\
\text { potential involvement of microRNA-126 } \\
\text { (miR-126) in the previous mechanisms }\end{array}$ & $\begin{array}{l}\text { NF- } k B, \text { ICAM-1, VCAM-1, and } \\
\text { PECAM-1, TNF- } \alpha\end{array}$ & PCR & $\begin{array}{l}\text { RWE at } 100 \mu \mathrm{g} / \mathrm{mL} \text { GAE partially } \\
\text { reversed the pro-inflammatory stimuli } \\
\text { by inducing miR-126 This indicates the } \\
\text { potential role of miR-126 in the } \\
\text { anti-inflammatory properties of } \\
\text { polyphenolics from red wine }\end{array}$ & [18] \\
\hline
\end{tabular}


Nicod and co-workers [15] and Nunes and co-workers [16,17] evaluated the effects of wine polyphenols on inflammatory biomarkers production by CaCo-2 and HT-29 cells, respectively. IL-6, IL-8, and COX-2 were significantly reduced in a concentration-dependent manner by the wine extracts. Different mechanisms of action were suggested by the authors [15-17]. Nicod et al. speculated that microbiota modulation could be involved in the biological effects observed, since the expression of selected genes encoding for inflammatory mediators (IL-6, IL-8, ICAM, COX 2) was not affected. Nunes et al. $[16,17]$ showed that wine polyphenols inhibited the NF- $k B$ cascade activation, responsible for the expression of several inflammatory cytokines, such as IL-8 and COX-2, factors playing an important role in inflammatory bowel diseases (IBD). A further mechanism could be responsible for the positive effects of wine: it is the JAK/STAT and Nrf2 (Nuclear Factor erythroid 2-related factor) signaling pathways activated during inflammatory condition in IBD. These results indicate that polyphenols from a red wine extract (RWE) could act on multiple targets. According to the authors and previous studies [19], anthocyanins, the major compounds in RWEs, could be the most important actor, although the contribution of other polyphenols cannot be excluded.

A different 'wine' extract from Lenoir grapes (Vitis aestivalis hybrid) was used by Angel-Morales et al. [18] to investigate the effects of wine polyphenols on human colon-derived CCD-18Co myofibroblast cells, which are involved in T-cell function modulation in IBD. In these pathological conditions several genes encoding for inflammatory mediators (granulocyte-macrophage colony-stimulating factor, interleukins IL-a, IL-b IL-6, IL-8) and adhesion molecules (intracellular adhesion molecule (ICAM-1), vascular cell adhesion molecule (VCAM-1)) are overexpressed in fibroblasts, as a consequence of inflammatory stimuli. This study focused on microRNAs (miRs), and in particular miR-126. MiRs are a class of endogenous noncoding RNAs, which are involved in post-transcriptional suppression of genes; miR-126 inhibits the expression of endothelial adhesion molecules reducing inflammation and, as a consequence, are an alternative target for the anti-inflammatory properties of natural components.

The induction of miR-126 by RWE (at the highest concentration, $100 \mu \mathrm{g} / \mathrm{mL}$ ) was the mechanism by which the extract decreased the expression of VCAM-1. Although the extract was not obtained from Vitis vinifera, the results suggest the potential role of miR-126 in the beneficial properties of red wine in a model of intestinal inflammation. For this reason, further studies should be conducted to investigate if a similar effect can be obtained from Vitis vinifera derivatives, including wine.

In a model of endothelial inflammation, Calabriso et al. [14] showed that endothelial adhesion molecules (e.g., VCAM-1, ICAM-1, monocyte chemoactractant protein-1 (MCP-1), and E-selectin) were reduced by the lowest concentration of wine polyphenols tested $(1 \mu \mathrm{g} / \mathrm{mL})$, through a down-regulation of mRNA levels. This effect was mediated by the inhibition of NF- $\mathrm{kB}$ DNA binding activity exerted by coumaric acid, kaempferol, and resveratrol. Unfortunately, the effects of wine anthocyanins were not assessed, making a comparison with the other in vitro studies impossible.

\subsection{In Vivo Studies}

\subsubsection{Animal Studies}

Table 2 lists the studies performed in animal models aimed to evaluate the effects of wine on inflammation parameters in different pathological conditions or physiological alterations, including myocardial infarction, oxidative stress, IBD, gastritis, and metabolic syndrome [20-26].

The animal studies were performed in mice or rats, which are considered a good model for nutritional and pharmacological trials, also considering the short time required to observe significant changes in biochemical parameters after treatment. The length of studies varied from 14 days to 6 months.

The moderate consumption of red wine has been associated with a broad spectrum of health-promoting effects, but the presence of ethanol in different amounts, raised concerns as to whether or not the polyphenol content can exert positive effects beyond the ethanol toxicity.

The anti-inflammatory activity of red wine was also evaluated in different models of inflammation/oxidative stress induced by a high fat or fructose diet [21,26], or granuloma [20]. 
Table 2. Summary of the collected animal studies used to assess effects of wine on inflammation biomarkers.

\begin{tabular}{|c|c|c|c|c|c|c|}
\hline Wine/Dosage & Animal Model & Aim & Biomarkers & Method & $\begin{array}{l}\text { Outcomes Showing } \\
\text { Significant Changes }\end{array}$ & Ref. \\
\hline \multicolumn{7}{|l|}{ Inflammation/Oxidative stress } \\
\hline $\begin{array}{l}\text { DRW }(350 \mathrm{~g} / \mathrm{kg}) \text { from Spain or } \\
\text { DWW }(350 \mathrm{~g} / \mathrm{kg}) \text { for } 15 \text { days } \\
\text { before carrageenan-granuloma } \\
\text { induction }\end{array}$ & $\begin{array}{l}\text { No. } 21 \text { adult male Sprague Dawley } \\
\text { rats were divided into three groups: } \\
\text { (1) control; (2) a 35\% (v/w) DRW } \\
\text { diet; (3) a 35\% (v/w) DWW diet }\end{array}$ & $\begin{array}{l}\text { To examine the effects DRW } \\
\text { and DWW on } \\
\text { carrageenan-granuloma } \\
\text { induced inflammation }\end{array}$ & $\begin{array}{l}\text { MDA, COX-2, iNOS } \\
\text { expression, NO, O2- } \\
\text { production by } \\
\text { polymorphonucleate cells }\end{array}$ & $\begin{array}{l}\text { MDA was measured by TBARS } \\
\text { test; free radicals reduction was } \\
\text { measured by ORAC assay; COX2 } \\
\text { and iNOS expression was } \\
\text { measured by electrophoresis and } \\
\text { Immunoblotting using } \\
\text { polyclonal antibodies }\end{array}$ & $\begin{array}{l}\text { In both treated groups there } \\
\text { was a decrease of MDA levels } \\
\text { in plasma. In the same groups } \\
\text { PMC showed decreased } \\
\text { superoxide anion production } \\
\text { and increased NO production; } \\
\text { COX-2 was upregulated } \\
\text { (pro-inflammatory effect) }\end{array}$ & [20] \\
\hline $\begin{array}{l}\text { RW Syrah, Cabernet } \\
\text { Sauvignon, and a blend from } \\
\text { Chile, Brazil, and Argentina, } \\
\text { respectively (alcohol content } \\
\text { 12-13\%). } \\
\text { Total period: } 4 \text { weeks }\end{array}$ & $\begin{array}{l}\text { No. } 50 \text { male Wistar rats divided in } 5 \\
\text { groups: (1) control diet; (2) high fat } \\
\text { diet }+770-1360 \mu \mathrm{L} \text { of water; }(3) \text { high } \\
\text { fat diet }+800-1380 \mu \mathrm{L} \text { of RW with } \\
\text { low antioxidant activity (LOW); }(4) \\
\text { high fat diet }+790-1170 \mu \mathrm{L} \text { of RW } \\
\text { with intermediate antioxidant } \\
\text { activity (MED) or (5) } 820-1340 \mu \mathrm{L} \text { of } \\
\text { RW with high antioxidant } \\
\text { activity (HIGH) }\end{array}$ & $\begin{array}{l}\text { To evaluate the effect of wine } \\
\text { on inflammation/oxidative } \\
\text { stress induced by a } \\
\text { high-fat diet }\end{array}$ & $\begin{array}{l}\text { MDA (lipid peroxidation) } \\
\text { Oxidative stress } \\
\text { Antioxidant enzyme } \\
\text { expression: superoxide } \\
\text { dismutase, catalase, and } \\
\text { GPx expression }\end{array}$ & $\begin{array}{l}\text { MDA was measured by TBAR } \\
\text { test; plasmatic antioxidant } \\
\text { activity was measured by ORAC } \\
\text { assay; expression of antioxidant } \\
\text { enzymes was measured } \\
\text { by electrophoresis }\end{array}$ & $\begin{array}{l}\text { Groups supplemented with } \\
\text { wines containing the highest } \\
\text { antioxidant activity (HIGH) } \\
\text { showed the lowest MDA } \\
\text { concentration in liver tissue. } \\
\text { All wines induced antioxidant } \\
\text { enzyme expression }\end{array}$ & [21] \\
\hline \multicolumn{7}{|l|}{ Myocardial infarction } \\
\hline $\begin{array}{l}\text { WW (Grasevina Krauthaker } \\
\text { vintage 2015, } 13 \% \text { alcohol) } \\
5 \mathrm{~mL} / 100 \mathrm{~g} \text { bw for } 4 \text { weeks }\end{array}$ & $\begin{array}{l}38 \text { Sprague Dawley male rats (one } \\
\text { month old) randomized into four } \\
\text { groups: one group including } \\
\text { animals drinking wine and three } \\
\text { reference groups }\end{array}$ & $\begin{array}{l}\text { To evaluate the effect of WW } \\
\text { consumption on granulocyte } \\
\text { and monocytes production } \\
24 \mathrm{~h} \text { after the surgically } \\
\text { incflicted MI. } \\
\text { This effect is positively } \\
\text { correlated with } \\
\text { tissue regeneration }\end{array}$ & $\begin{array}{l}\text { CD15s, CD11b, and CD44, } \\
\text { MMP-9 expression }\end{array}$ & Flow cytometry & $\begin{array}{l}\text { White wine consumption } \\
\text { caused a 3.2-fold (95\% CI } 1.569 \\
\text { to } 3.86, p<0.0001 \text { ) increase in } \\
\text { CD44 expression on monocytes } \\
\text { in comparison to the water } \\
\text { drinking controls. } \\
\text { CD44 expression on } \\
\text { granulocytes from wine group } \\
\text { was slightly increased ( } p= \\
0.0203 \text { ) in comparison } \\
\text { to controls }\end{array}$ & [22] \\
\hline $\begin{array}{l}\text { WW Grasevina Krauthaker } \\
\text { vintage } 2015 \text {, } \\
13 \% \text { ethanol) } \\
6 \mathrm{~mL} / 100 \mathrm{~g} \mathrm{bw} \\
\text { For } 4 \text { weeks }\end{array}$ & $\begin{array}{l}24 \text { Sprague Dawley male rats } \\
\text { randomized into } 2 \text { groups: } \\
\text { control/water and wine }\end{array}$ & $\begin{array}{l}\text { To investigate the effects of } \\
\text { WW consumption on the } \\
\text { expression of inflammatory } \\
\text { mediators in myocardial } \\
\text { tissue after induced } \\
\text { myocardial ischemia }\end{array}$ & $\begin{array}{l}\text { Three representative } \\
\text { myocardial areas were } \\
\text { identified and analyzed for } \\
\text { inflammatory mediators } \\
\text { (MMP-9, MMP-2, NF-kB, } \\
\text { TG- } \beta 1 \text { ) expression: } \\
\text { infarct/ischemic, } \\
\text { peri-infarct/border zone, and } \\
\text { control/non-ischemic zones }\end{array}$ & Immunochemistry & $\begin{array}{l}\text { MMP-9 were less expressed in } \\
\text { all } 3 \text { zones of wine drinking } \\
\text { animals }(p<0.001) . \text { MMP- } 2 \\
\text { expression was significantly } \\
\text { decreased only in } \\
\text { peri-infarctual zones }(p<0.001) \text {. } \\
\text { Same pattern of expression was } \\
\text { found for the NF-kB signal }\end{array}$ & [23] \\
\hline
\end{tabular}


Table 2. Cont.

\begin{tabular}{|c|c|c|c|c|c|c|}
\hline Wine/Dosage & Animal Model & Aim & Biomarkers & Method & $\begin{array}{l}\text { Outcomes Showing } \\
\text { Significant Changes }\end{array}$ & Ref. \\
\hline \multicolumn{7}{|l|}{ Gastric/Intestinal function } \\
\hline $\begin{array}{l}\text { MGE and MWE } 500 \mathrm{mg} / \mathrm{kg} \text { bw } \\
\text { of mice for } 14 \text { days }\end{array}$ & $\begin{array}{l}32 \text { female C57BL/6J mice } \\
\text { (8-week-old) randomly divided into } \\
\text { four groups: (1) healthy mice } \\
\text { (control) receiving water; (2) disease } \\
\text { control group; (3-4) treated } \\
\text { colitic mice }\end{array}$ & $\begin{array}{l}\text { To determine the } \\
\text { anti-inflammatory effects of } \\
\text { phytochemical extracts on } \\
\text { DSS-induced colitis in mice } \\
\text { and to investigate } \\
\text { cellular mechanisms. }\end{array}$ & $\begin{array}{l}\text { IL-1 } \beta \text {, IL- } 6 \text {, and TNF- } \alpha \\
\text { MPO activity }\end{array}$ & $\begin{array}{l}\text { Mouse cytokine magnetic bead } \\
\text { panel (immunochemical test) } \\
\text { Spectrophotometric measurement }\end{array}$ & $\begin{array}{l}\text { Phytochemicals from MGE or } \\
\text { MWE mitigate ulcerative colitis } \\
\text { via attenuation of pro- } \\
\text { inflammatory cytokine } \\
\text { production, modulation of the } \\
\text { NF- } \mathrm{kB} \text { pathway, } \\
\text { and MPO activity. }\end{array}$ & [24] \\
\hline $\begin{array}{l}\text { DRW } 5 \mathrm{~mL} / \text { mouse/day } \\
\text { Total days } 14 \text { days, last } 4 \text { days } \\
\text { treated with wine (treatment } \\
\text { group) or water (control group) }\end{array}$ & $\begin{array}{l}\text { BALB/c mice (6-week old average } \\
\text { bw18 g) received daily two } \\
\text { intragastric administrations of VacA }\end{array}$ & $\begin{array}{l}\text { To investigate whether RW } \\
\text { influences gastric } \\
\text { inflammation in } \\
\text { VacA-treated mice (toxin } \\
\text { produced by H. pylori) }\end{array}$ & Alteration of gastric mucosa & $\begin{array}{l}\text { Hystological examination of } \\
\text { mucosal alterations and IHC } \\
\text { staining using an antiVacA } \\
\text { monoclonal antibody }\end{array}$ & $\begin{array}{l}\text { The mucosal alterations were } \\
\text { significantly milder in mice } \\
\text { receiving RW vs. control mice. } \\
\text { RW significantly prevented } \\
\text { gastric epithelium damage in } \\
\text { VacA-treated mice }\end{array}$ & [25] \\
\hline \multicolumn{7}{|l|}{ Metabolic syndrome } \\
\hline $\begin{array}{l}\text { Total period: } 10 \text { weeks; in the } \\
\text { last } 4 \text { weeks animals were } \\
\text { treated with RW. (Malbec) } \\
35 \mathrm{~mL} / \mathrm{kg} \text { bw }\end{array}$ & $\begin{array}{l}\text { No. } 40 \text { 30-day old male Wistar rats } \\
\text { were assigned to four groups: } \\
\text { 1-water group (control), } 2-\mathrm{F}(10 \% \\
\text { fructose in drinking water), } 3-\mathrm{F}+\mathrm{E} \\
(10 \% \text { fructose + ethanol } 4.5 \mathrm{~mL} / \mathrm{kg}) \text {, } \\
4-\mathrm{F}+\mathrm{RW}(35 \mathrm{~mL} / \mathrm{kg} \text { containing } \\
4.5 \mathrm{~mL} \text { alcohol). }\end{array}$ & $\begin{array}{l}\text { To evaluate the effects of } \\
\text { moderate consumption of } \\
\text { RW or ethanol on } \\
\text { adiponectin, resistin } \\
\text { expression, and vascular } \\
\text { alterations in FFrs as an } \\
\text { experimental model of MS. }\end{array}$ & $\begin{array}{l}\text { Oxidative stress } \\
\text { Adiponectin and resistin }\end{array}$ & $\begin{array}{l}\text { Adiponectin, resistin, VCAM-1, } \\
\text { and NF- } \mathrm{kB} \text { protein expression } \\
\text { were evaluated by WB analysis }\end{array}$ & $\begin{array}{l}\mathrm{RW} \text { administration to F rats } \\
\text { was able to significantly } \\
\text { decrease insulin resistance, } \\
\text { mesenteric adipose tissue } \\
\text { weight, and SbP compared to } \mathrm{F} \\
\text { group. } \mathrm{F}+\mathrm{RW} \text { reduced } \\
\text { adiponectin } \\
\text { expression decreased }\end{array}$ & [26] \\
\hline
\end{tabular}

CD: cluster of differentiation; COX-2: cyclooxigenase-2; DRW: dealcoholized red wine; DSS: dextran sulphate sodium; DWW: dealcoholized white wine; E: ethanol; F: fructose; FFrs: fructose-fed rats; GPx: gluthatione peroxidase; IHC: immunohistochemistry; IL: interleukin; MDA: malondyaldehide; MED: medium; MGE: Muscadine grape extract; MI: myocardial infarction; MMP: matrix metallopeptidase; MPO: myeloperoxidase; MS: metabolic syndrome; MWE: Muscadine wine extract; NF- $\mathrm{KB}$ : nuclear factor-k light chain enhancer of activated B cells; ORAC: oxygen radical absorbance capacity; PCM: polymorphonucleates; RW: red wine; SbP: systolic blood pressure; TBARS: thiobarbituric acid reactive substances; TNF- $\alpha$ : tumor necrosis factor $\alpha$; WB: Western blot; WW: white wine. 
Red wine significantly reduced some parameters of oxidative stress, such as 8-hydroxy-2'deoxyguanosine (8-OHdG) and malondialdehyde (MDA), biomarkers of DNA and lipid oxidation, respectively. In addition, Lopez and co-workers [20], investigating the possible differences between dealcoholized red (DRW) and white (DWW) wines, showed a greater antioxidant activity of DWR in vitro and in vivo models. This was probably due to the higher content of polyphenol, ascorbic acid and sulfites, and to the contribution of wine polyphenols in producing uric acid [10]. According to Vazquez-Prieto and co-workers [26], the effects of the red wine can be attributed to the polyphenol content (total phenol content: $2.9 \mathrm{~g} / \mathrm{L}$ gallic acid equivalents); in particular, catechin $(24 \mathrm{mg} / \mathrm{L})$ and resveratrol $(1.1 \mathrm{mg} / \mathrm{L})$ could be involved in the reduction of fat oxidation and the inhibition of preadipocyte proliferation.

The evaluation of oxidative stress was investigated, as secondary end-point, in several other studies since it is involved in the development of several disorders, including cardiovascular diseases.

Since data on biological effects of white wine are quite scarce in comparison with red wine, Rezic-Munizic et al. [22] and Kljucevic et al. [23], evaluated the effects of white wine on inflammatory biomarkers after myocardial infarction in rats. When compared to controls, wine consumption was associated with the increase in CD44 (cluster of differentiation 44) expression (0.2-fold, $p<0.0203$ ), which has a role in fibrous tissue deposition in the healing infarct and in cardiac regeneration. White wine is relatively rich in non-flavonoid compounds, such as phenolic acids (derivatives of hydroxybenzoic and hydroxycinnamic acid) and other phenols such as tyrosol, that could mediate the effect on CD44 expression. A similar study was performed by Kljucevic et al. [23], who found a significant reduced expression of MMP-2 and MMP-9 (matrix metalloproteinases) in all the representative myocardial areas identified: infarct/ ischemic, peri-infarct/border zone, and control/non-ischemic zones $(p<0.001)$. This indicates a potential role of white wine in improving the inflammatory condition associated with cardiovascular impairment, since MMPs are responsible for the cleavage of several extracellular matrix proteins (activating cytokine production) and modulate the course and outcome of myocardial infarction. According to the authors' conclusions, however, this effect is not due to inhibition of the NF- $\mathrm{kB}$ pathway mediated by polyphenols. Unfortunately, neither of the two studies reported the chemical characterization of wine, making it difficult to establish a correlation between polyphenol content and the biological effects observed.

Finally, as in in vitro models, wine was evaluated in gastric and intestinal inflammation. Ethanol free RWE (5 mL/day) showed to be effective in reducing epithelial gastric damage induced in BALB/c mice by purified VacA (a vacuolar toxin produced by H. pylori), but not in influencing gastric colonization levels, probably because other mechanisms of infection by $H$. pylori are involved [25]. Considering that gastritis may be caused by other factors, including lifestyle, further studies should be performed on the effect of wine on gastric mucosa, taking also into account the content of ethanol (one of the most important gastric inflammation inductor) and phenolic compounds.

In a murine model of colitis, a treatment with a dealcoholized RWE (500 mg/ kg bw) from muscadine grape (Vitis rotundifolia) was able to significantly reduce fecal myeloperoxidase (MPO) expression (from 10.4 to 5.39 units/mg of tissue); MPO is a pro-oxidative and pro-inflammatory enzyme produced by neutrophils and monocytes, which accumulates in intestinal mucosa in ulcerative colitis. The authors speculated that this effect could be mediated by anthocyanins [27], the content of which was $171.2 \mathrm{mg} / \mathrm{g}$, more than half of the total polyphenol amount present in the extract.

\subsubsection{Human Studies}

Table 3 describes the studies in humans performed to evaluate the effects of wine on inflammation, with indication of the models used. Twelve among the 15 trials were performed on healthy subjects. They were generally designed as randomized, controlled, and cross-over studies where the targets were the cardiovascular and immune function. To evaluate the effect of "acute" consumption on inflammation, wine intake ranged from $150 \mathrm{~mL}$ to $500 \mathrm{~mL}$ /day in a single dose; to simulate the "regular" intake the period was longer: from 15 days up to 12 months. When reported, total polyphenol content of wine varied from 1.5 to $3.0 \mathrm{~g} / \mathrm{L}$ [28-43]. 
Table 3. Summary of the collected human trials to assess effects of wine on inflammation biomarkers

\begin{tabular}{|c|c|c|c|c|c|c|}
\hline Cohort, Sample Size & Wine Intake/Duration & Aim & Biomarkers & Biomarkers Measurement & Outcomes & Ref. \\
\hline \multicolumn{7}{|l|}{ Cardiovascular system } \\
\hline $\begin{array}{l}38 \text { healthy adults (wine } \\
\text { consumers } 61.44 \pm 2.58 \mathrm{y} ; \\
\text { non-consumers: } \\
60.73 \pm 3.74 \text { y) }\end{array}$ & $\begin{array}{l}\text { Wine intake was assessed by annual } \\
\text { frequency questionnaire }\end{array}$ & $\begin{array}{l}\text { To bear out the association } \\
\text { between the regular } \\
\text { consumption of RW and } \\
\text { some biomarkers of } \\
\text { antioxidant status, } \\
\text { lipid peroxidation, } \\
\text { and inflammation }\end{array}$ & CRP & CRP human instant ELISA & $\begin{array}{l}\text { No significant differences in } \\
\text { CRP concentrations between } \\
\text { RW consumers (mean intake = } \\
100 \mathrm{~mL} \text { ) and non-consumers }\end{array}$ & {$[28]$} \\
\hline $\begin{array}{l}87 \text { participants (mean age } \\
50.2 \pm 9.6 \mathrm{y} \text { ) }\end{array}$ & $\begin{array}{l}\text { Daily ingestion of one glass of } \\
\text { RW/day (Cabernet Sauvignon, } \\
150 \mathrm{~mL}, 15 \mathrm{~g} \text { of alcohol) or total } \\
\text { abstention. Intervention switch after } \\
3 \text { weeks with no wash-out }\end{array}$ & $\begin{array}{l}\text { To study the acute effect of } \\
\text { RW on the levels of the } \\
\text { inflammatory markers }\end{array}$ & CRP, Fib & $\begin{array}{l}\text { ELISA (CRP); Fib: Clauss' assay } \\
\text { (based on time for fibrin } \\
\text { clot formation) }\end{array}$ & $\begin{array}{l}\text { The consumption of } 150 \mathrm{~mL} \text { of } \\
\text { RW slightly reduced Fib }(3 \%) \\
\text { levels but did not reduce CRP } \\
\text { levels in comparison with } \\
\text { total abstention }\end{array}$ & [29] \\
\hline $\begin{array}{l}10 \text { healthy men (mean } \\
\text { age: } 31.4 \pm 4.3 \mathrm{y})\end{array}$ & $\begin{array}{l}\text { On four different days each subject } \\
\text { consumed (with meals): } 4 \mathrm{~mL} / \mathrm{bw} \text { of } \\
\text { (1) WW (Robola variety), (2) RW } \\
\text { (Cabernet Sauvignon variety); } \\
\text { (3) ethanol solution (12,5\% alcohol); } \\
\text { (4) water } \\
\text { 2-week wash out between } \\
\text { treatments were requested }\end{array}$ & $\begin{array}{l}\text { To evaluate the acute effect of } \\
\text { wine consumption on } \\
\text { platelet aggregation (T0-6 h } \\
\text { after intake) }\end{array}$ & PAF, PAI-I & ELISA & $\begin{array}{l}\text { At } 150 \text { min significant } \\
\text { inhibition of platelet } \\
\text { aggregation by RW (but not } \\
\text { WW) vs. ethanol and water } \\
\text { At } 210 \text { min platelet aggregation } \\
\text { by RW vs. water }\end{array}$ & [30] \\
\hline $\begin{array}{l}12 \text { healthy participants } \\
\text { (mean age } 31.3 \pm 4.3 \mathrm{y})\end{array}$ & $\begin{array}{l}\text { In } 4 \text { different days each subject } \\
\text { consumed (with meals): } 4 \mathrm{~mL} / \mathrm{bw} \text { of } \\
\text { (1) WW (Robola variety), (2) RW } \\
\text { (Cabernet Sauvignon variety); } \\
\text { (3) ethanol solution (12,5\% alcohol); } \\
\text { (4) water } \\
\text { 2-week wash out between } \\
\text { treatments were requested }\end{array}$ & $\begin{array}{l}\text { To investigate the acute effect } \\
\text { of wine consumption, on } \\
\text { platelet aggregation and } \\
\text { inflammation }\end{array}$ & $\begin{array}{l}\text { PAF biosynthetic } \\
\text { enzymes: Lyso-PAF AT } \\
\text { and PAF-CPT, catabolic } \\
\text { enzyme LpPLA2; } \\
\text { IL-6 levels }\end{array}$ & $\begin{array}{l}\text { Platelet aggregation assay [31]; } \\
\text { ELISA }\end{array}$ & $\begin{array}{l}\text { Both RW and WW decreased } \\
\text { enzyme activity compared to } \\
\text { ethanol. The protective effect } \\
\text { of light to moderate wine (RW } \\
\text { and WW) consumption could } \\
\text { partly be explained through } \\
\text { the modulation of PAF levels } \\
\text { by decreasing their } \\
\text { biosynthetic activities. } \\
\text { No differences among } \\
\text { treatments were observed on } \\
\text { IL-6 level reduction }\end{array}$ & [32] \\
\hline $\begin{array}{l}83 \text { participants (mean age } \\
25.2 \pm 1.1 \mathrm{y})\end{array}$ & $\begin{array}{l}\text { Participants were divided in } 5 \\
\text { groups: (1) } 264 \mathrm{~mL} \text { RW; (2) } 264 \mathrm{~mL} \\
\text { WW; (3) } 633 \mathrm{~mL} \text { of beer; (4) } 79 \mathrm{~mL} \\
\text { whisky; (5) } 264 \mathrm{~mL} \text { water for } 4 \text { weeks }\end{array}$ & $\begin{array}{l}\text { To examine the effect of acute } \\
\text { administration of equivalent } \\
\text { amount of alcohol }(30 \mathrm{~g}) \text { in } \\
\text { different alcoholic beverages, } \\
\text { on endothelial function and } \\
\text { inflammatory processes } \\
\text { ( } \mathrm{T}=4 \mathrm{~h} \text { after intake) }\end{array}$ & $\begin{array}{l}\text { IL-6, TNF- } \alpha, \text { CRP, Fib, } \\
\text { PAI-1, vWf, tPA }\end{array}$ & ELISA & $\begin{array}{l}\text { Only RW and beer significantly } \\
\text { improved endothelial function } \\
\text { and decrease vWf levels, } 4 \mathrm{~h} \\
\text { after consumption }(p<0.05 \text { for } \\
\text { both) vs. controls. In the same } \\
\text { groups reactive hyperemia was } \\
\text { significantly increased } 1 \mathrm{~h} \text { after } \\
(p<0.05 \text { for both), while it } \\
\text { returned at baseline at } 4 \mathrm{~h} \text {. }\end{array}$ & [33] \\
\hline
\end{tabular}


Table 3. Cont

\begin{tabular}{|c|c|c|c|c|c|c|}
\hline Cohort, Sample Size & Wine Intake/Duration & Aim & Biomarkers & Biomarkers Measurement & Outcomes & Ref. \\
\hline $\begin{array}{l}34 \text { women (mean age } \\
38 \pm 8.5 \text { y) }\end{array}$ & $\begin{array}{l}\text { Participants were randomly } \\
\text { assigned to two } 4 \text {-week periods of } 20 \\
\text { g ethanol/d as WW or RW (1 glass } \\
\text { of } 100 \mathrm{~mL} \text { at lunch and at dinner), } \\
\text { with two } 4 \text {-week washout periods. }\end{array}$ & $\begin{array}{l}\text { To investigate whether low } \\
\text { intake of WW or RW has } \\
\text { differential effects on } \\
\text { inflammatory markers } \\
\text { in women }\end{array}$ & $\begin{array}{l}\text { hs-CRP, ICAM-1, } \\
\text { VCAM-1, } \\
\text { E-selectin, } \\
\text { P-selectin, CD40L, IL-6 }\end{array}$ & $\begin{array}{l}\text { hs-CRP: particle-enhanced IN; } \\
\text { ICAM-1, VCAM-1, E-selectin, } \\
\text { P-selectin, CD40L: ELISA }\end{array}$ & $\begin{array}{l}\text { Both RW and WW reduced } \\
\text { hs-CRP, ICAM-1, CD40L, IL-6 } \\
\text { levels }(p<0.01) \text { and CAMs } \\
\text { expression by mononuclear } \\
\text { cells (greater effect for RW). } \\
\text { VCAM- } 1 \text { and E-selectin } \\
\text { decreased ( } p<0.01 \text { ) only in } \\
\text { RW group. }\end{array}$ & [34] \\
\hline $\begin{array}{l}48 \text { subjects (mean age } \\
43.6 \pm 10.6 \mathrm{y} \text { ) }\end{array}$ & $\begin{array}{l}\text { Participants were randomly } \\
\text { assigned to two } 4 \text {-week periods of } \\
\text { Sicilian RW consumption ( } 250 \mathrm{~mL} / \mathrm{d} \\
\text { Nero d'Avola or } 250 \mathrm{~mL} / \mathrm{d} \text { Etna } \\
\text { Torrepalino-Solicchiata at meals), } \\
\text { with 4-week washout periods. }\end{array}$ & $\begin{array}{l}\text { To evaluate the effect of } \\
\text { moderate RW consumption } \\
\text { on some inflammatory } \\
\text { biomarkers associated with } \\
\text { cardiovascular risk factor }\end{array}$ & $\begin{array}{l}\text { Plasma CRP, TGF- } \beta 1 \text {, } \\
\text { D-Dimer, Factor VII, PAI } \\
\text { Ag, tPA Ag, Fib, oxidized } \\
\text { LDL Ab, TPAC }\end{array}$ & $\begin{array}{l}\text { ELISA; } \\
\text { ORAC assay for } \\
\text { antioxidant activity }\end{array}$ & $\begin{array}{l}\text { Both RW reduced Fib, factor } \\
\text { VII, plasma CRP and oxidized } \\
\text { LDL levels, while TGF- } \beta 1, \text { tPA, } \\
\text { PAI, and TPAC were } \\
\text { significantly increased. }\end{array}$ & [35] \\
\hline $\begin{array}{l}40 \text { healthy adult men } \\
\text { (mean age: } 37.6 \pm 7.4 \text { y) }\end{array}$ & $\begin{array}{l}\text { Participants consumed two } 160 \mathrm{~mL} \\
\text { glasses of RW (Merlot) or } 100 \mathrm{~mL} \text { gin } \\
\text { (both } 30 \mathrm{~g} \text { of ethanol) for } 28 \text { days } \\
\text { with } 15 \text { days wash out } \\
\text { between treatments }\end{array}$ & $\begin{array}{l}\text { To evaluate the effects of } \\
\text { wine and gin on } \\
\text { inflammatory biomarkers of } \\
\text { atherosclerosis }\end{array}$ & $\begin{array}{l}\text { LFA-1, VLA-4, MCP-1, } \\
\text { VCAM-1, ICAM-1, } \\
\text { IL-1 } \alpha, \text { hs-CRP and Fib }\end{array}$ & ELISA & $\begin{array}{l}\text { Both gin and RW reduced } \\
\text { plasma Fib and IL- } 1 \alpha \text { levels. } \\
\text { Only RW reduced serum } \\
\text { concentrations of hs-CRP } \\
(-21 \%), \text { VCAM-1 }(-17 \%) \text { and } \\
\text { ICAM-1 }(-9 \%) \text {. }\end{array}$ & [36] \\
\hline $\begin{array}{l}20 \text { healthy adults } \\
(\text { mean age } 31.1 \pm 0.8 \mathrm{y})\end{array}$ & $\begin{array}{l}\text { All participants smoked } 3 \text { cigarettes; } \\
\text { n. } 10 \text { subjects consumed } 1 \mathrm{~h} \text { before } \\
\text { smoking an amount of RW (Chateau } \\
\text { Haut-Pontet) aiming to reach } 0.075 \% \\
\text { blood alcohol content. }\end{array}$ & $\begin{array}{l}\text { To evaluate whether RW } \\
\text { consumption counteracts the } \\
\text { adverse vascular effects of } \\
\text { acute cigarette smoking. }\end{array}$ & $\begin{array}{l}\text { IL-6, TNF- } \alpha, \text { IL-1b } \\
\text { expression, CD14, } \\
\text { leukocytes }\end{array}$ & ELISA & $\begin{array}{l}\text { Wine significantly reduced } \\
\text { endothelial, platelet-, } \\
\text { monocyte-, and } \\
\text { leukocyte-derived } \\
\text { microparticles ( } p<0.001 \text { each) } \\
\text { and mRNA expression of IL-6, } \\
\text { TNF- } \alpha \text {, and IL-1b in monocytes } \\
\text { vs. only smokers }\end{array}$ & [37] \\
\hline $\begin{array}{l}13 \text { subjects with CAD } \\
\text { (mean age } 59.1 \pm 7.0 \text { ) }\end{array}$ & $\begin{array}{l}\text { Participants received } 4 \mathrm{~mL} / \mathrm{kg} \mathrm{bw}(2 \\
\text { to } 3 \text { glasses, corresponding to } 0.52 \mathrm{~g} \\
\text { alcohol } / \mathrm{kg} \text { bw) of RW (Stoneleigh } \\
\text { Marlborough Pinot Noir) or WW } \\
\text { (Jackson Estate Marlborough } \\
\text { Sauvignon Blanc) at meals, with } \\
\text { 1-week wash out between } \\
\text { interventions. } \\
\text { Three months after wine study, } \\
\text { subjects received a non-alcoholic } \\
\text { beverage } 4 \mathrm{~mL} / \mathrm{kg} \text { bw at meals }\end{array}$ & $\begin{array}{l}\text { To compare the acute effects } \\
\text { of ingestion of RW and WW } \\
\text { ( } \mathrm{T}=6 \mathrm{~h} \text { after intake) on } \\
\text { markers of inflammation in } \\
\text { men with CAD. }\end{array}$ & IL-6, VCAM-1, ICAM-1 & ELISA & $\begin{array}{l}\text { Acute RW and WW intake } \\
\text { significantly increase plasma } \\
\text { levels of IL-6 vs. } \\
\text { non-alcoholic beverages }\end{array}$ & [38] \\
\hline
\end{tabular}


Table 3. Cont.

\begin{tabular}{|c|c|c|c|c|c|c|}
\hline Cohort, Sample Size & Wine Intake/Duration & Aim & Biomarkers & Biomarkers Measurement & Outcomes & Ref. \\
\hline \multicolumn{7}{|l|}{ Immune function } \\
\hline $\begin{array}{l}27 \text { healthy subjects (mean } \\
\text { age } 28 \pm 6.3 \text { ) }\end{array}$ & $\begin{array}{l}\text { The study was performed in } \\
\text { two parts: } \\
\text { 1-Bolus study } \\
\text { Participants received: } 200 \mathrm{~mL} \text { RW } \\
\text { (Marienthaler Spatburgunder } \\
\text { Klostergarten, } 12 \% \text { ethanol) (No. 9) } \\
\text { or } 200 \mathrm{~mL} \text { DRW (Marienthaler } \\
\text { Spatburgunder Klostergarten) } \\
\text { (No. 9) or } 200 \mathrm{~mL} \text { water (No. 9) } \\
\text { 2-Dietary intervention study } \\
\text { (6-week) } \\
\text { Subjects ingested } 200 \mathrm{~mL} \mathrm{RW} \text { (n.27), } \\
175 \mathrm{~mL} \text { DRW (n. 26), water } 200 \mathrm{~mL} \\
\text { (n. 25) } 1 \mathrm{~h} \text { after dinner }\end{array}$ & $\begin{array}{l}\text { To evaluate effect of acute } \\
\text { ( } \mathrm{T}=360 \text { min after intake) and } \\
\text { regular consumption } \\
\text { ( } 6 \text { weeks) of wine on } \\
\text { immunological parameters }\end{array}$ & $\begin{array}{l}\mathrm{T} \text { cell apoptosis, } \\
\text { granulocytes, and } \\
\text { monocytes phagocytosis }\end{array}$ & $\begin{array}{l}\text { Annexin V fluorescein } \\
\text { isothocyanate } \\
\text { (FICT)/DNA-labeling } \\
\text { flow-cytometry (Phagotest) }\end{array}$ & $\begin{array}{l}\text { Only acute intake of RW } \\
\text { decreased T cell apoptosis } \\
(p=0.006 \text { vs. } p=0.024 \\
\text { of controls). } \\
\text { No other significant changes } \\
\text { were observed among groups }\end{array}$ & [39] \\
\hline $\begin{array}{l}24 \text { healthy non-smoking } \\
\text { men (mean age } \\
30.6 \pm 1.4 \text { y) }\end{array}$ & $\begin{array}{l}\text { Subjects were randomly assigned to } \\
\text { consume for } 15 \text { days } 500 \mathrm{~mL} / \text { day of } \\
\text { RW (Lemberger, } 12 \% \text { ETOH v/v), } \\
\text { DRW, RGJ (var Lemberger), and } \\
\text { ETOH ( } 12 \% \text { ethanol v/v), with a } \\
\text { wash-out period of 1-week between } \\
\text { each experimental treatment }\end{array}$ & $\begin{array}{l}\text { To investigate: (1) whether } \\
\text { daily consumption of a } \\
\text { moderate volume of RW } \\
\text { modulates immune functions } \\
\text { in healthy men in } 2 \text { weeks; } \\
\text { (2) polyphenols in RW induce } \\
\text { changes in immune functions } \\
\text { vs. a 12\% ETOH beverage. }\end{array}$ & $\begin{array}{l}\text { Phagocytic activity of } \\
\text { neutrophils and } \\
\text { monocytes, production of } \\
\text { TNF } \alpha \text {, IL-2 and IL-4, } \\
\text { TGF- } \beta \text {, expression of } \\
\text { TNF- } \alpha \text { mRNA, } \\
\text { lymphocyte proliferation, } \\
\text { lytic activity of NK cells, } \\
\text { and percentage of } \\
\text { apoptotic lymphocytes. }\end{array}$ & $\begin{array}{l}\text { By flow-cytometry: } \\
\text { lytic activity, phagocytosis and } \\
\text { apoptosis } \\
\text { by immunoassay: } \\
\text { lymphocyte proliferation and } \\
\text { cytokine secretion. }\end{array}$ & $\begin{array}{l}\text { Consumption of a moderate } \\
\text { volume of alcohol with RW } \\
\text { and with a } 12 \% \text { ETOH, or RGJ } \\
\text { had no effect on immune } \\
\text { functions in healthy males. }\end{array}$ & [40] \\
\hline \multicolumn{7}{|l|}{ Type 2 diabetes } \\
\hline $\begin{array}{l}24 \text { T2D patients } \\
\text { (mean age: } 59.3 \pm 1.1 \mathrm{y} \text { ) } \\
\text { and } 22 \text { healthy volunteers } \\
\text { (mean age: } 54.1 \pm 1.4 \mathrm{y} \text { ) }\end{array}$ & $\begin{array}{l}\text { Three study periods, each of 4-week } \\
\text { (with no wash out): (1) RW } \\
\text { (Shiraz Cabernet, 13\% alcohol) } \\
\text { (women: } 230 \mathrm{~mL} / \text { day men: } \\
300 \mathrm{~mL} / \text { day) at dinner; (2) DRW } \\
\text { (Shiraz Cabernet (women: } \\
230 \mathrm{~mL} / \text { day men: } 300 \mathrm{~mL} / \text { day) at } \\
\text { dinner; (3) Water }\end{array}$ & $\begin{array}{l}\text { To examine the effects of RW } \\
\text { on plasmatic SPMs, involved } \\
\text { in promoting homeostasis } \\
\text { after flogistic events }\end{array}$ & $\begin{array}{l}\text { SPMs included: } \\
\text { 18-HEPE, 17-HDHA, } \\
\text { 14-HDHA, resolvins, } \\
\text { and protectins }\end{array}$ & LC/MS-MS & $\begin{array}{l}\text { RW did not differentially affect } \\
\text { any of the SPMs measured in } \\
\text { T2D patients when compared } \\
\text { with DRW or water. }\end{array}$ & [41] \\
\hline \multicolumn{7}{|l|}{ Type 2 diabetes } \\
\hline $\begin{array}{l}115 \text { subjects with T2D } \\
\text { with recent history of MI } \\
\text { (mean age } 35.5 \pm 5.5 \mathrm{y} \text { ) }\end{array}$ & $\begin{array}{l}\text { Patients received } 118 \mathrm{~mL} / \text { day RW } \\
\text { (Barbera, } 11 \mathrm{~g} \text { alcohol) with meals or } \\
\text { not alcoholic beverages for } \\
12 \text { months }\end{array}$ & $\begin{array}{l}\text { To examine the effects of } \\
\text { moderate RW intake, with } \\
\text { meals, on cardiac functions } \\
\text { and inflammatory cytokine } \\
\text { levels in T2D patients } \\
\text { after MI }\end{array}$ & CRP, TNF- $\alpha$, IL-6, IL-18 & $\begin{array}{l}\text { Highly sensitive, quantitative } \\
\text { sandwich enzyme assay } \\
\text { CRP: IN }\end{array}$ & $\begin{array}{l}\text { RW in the intervention group } \\
\text { significantly reduced } \\
\text { pro-inflammatory cytokines } \\
\text { CRP, TNF- } \alpha \text {, IL-6, IL-8 vs. } \\
\text { control group }\end{array}$ & [42] \\
\hline
\end{tabular}


Table 3. Cont

\begin{tabular}{|c|c|c|c|c|c|c|}
\hline Coho & ne 1 & $n$ & iomarkers & Biomarkers Measurement & Outcomes & $\overline{\text { Ref. }}$ \\
\hline $\begin{array}{l}801 \text { participa } \\
688.5 \pm 7.2 \text { ye }\end{array}$ & $\begin{array}{l}\text { Subjects were classified as } \\
\text { non-consumers (no consumption of } \\
\text { alcohol-containing beverages } \\
\text { including wine); moderate } \\
\text { consumers and high consumers } \\
\text { (men: ethanol intake }>20 \mathrm{~g} / \mathrm{d} \text {; } \\
\text { women: ethanol intake }>10 \mathrm{~g} / \mathrm{d} \text { ). }\end{array}$ & $\begin{array}{l}\text { To investigate the association } \\
\text { between wine consumption } \\
\text { and endothelial dysfunction } \\
\text { and low-grade inflammation }\end{array}$ & $\begin{array}{l}\text { Endothelial dysfunction } \\
\text { was evaluated using } \\
\text { Z-scores (higher scores } \\
\text { indicate worse function) } \\
\text { for: vWf, sE-selectin, } \\
\text { sTM, sVCAM- } 1 \text { and } \\
\text { sICAM-1, low-grade } \\
\text { inflammation: CRP, SAA, } \\
\text { IL-6, IL-8, TNF- } \alpha \text { and } \\
\text { sICAM-1 }\end{array}$ & $\begin{array}{l}\text { Multiarray detection system } \\
\text { based on ECL technology } \\
\text { vWf: ELISA }\end{array}$ & $\begin{array}{l}\text { Wine consumption was } \\
\text { associated with a lower } \\
\text { endothelial dysfunction vs. } \\
\text { wine abstention but not vs. } \\
\text { alcohol intake }\end{array}$ & [43] \\
\hline \multicolumn{7}{|c|}{$\begin{array}{l}\text { Ab: antibody; Ag: antigen; CAD: coronary artery disease; CAMs: cellular adhesion molecule; CD: clusters of differentiation; CRP: C-reactive protein; DRW: dealcoholized red wine; ECL: } \\
\text { lectrochemiluminescence; ELISA: enzyme-linked immunosorbent assay; Fib: Fibrinogen; FICT: fluorescent immunochromatographic strip test; HDHA: hydroxydocosahexaenoic acid; } \\
\text { HEPE: hydroxyeicosapentaenoic acid; hs-CRP: high-sensitivity C-reactive protein; ICAM: intercellular adhesion molecule; IL: interleukin; IN: immunonephelometry; LC-MS/MS: liquid } \\
\text { hromatography-tandem mass spectrometry; LDL: low density lipoprotein; LFA: lymphocyte function-associated; LpPLA2: lipoprotein-associated phospholipase A2; Lyso-PAF AT: } \\
\text { yso-platelet-activating factor acetyltransferase; MCP: monocyte chemoattractant protein; MI: myocardial infarction; mRNA: messenger RNA; NK: natural killer cell; ORAC: oxygen } \\
\text { adicals absorbance capacity; PAF CPT: platelet-activating factor-cholinephosphotransferase; PAF: platelet-activating factor; PAI: plasminogen activator inhibitor; RGJ: red grape juice; RW: } \\
\text { ed wine; SAA: serum amyloid A; sE-selectin: soluble E-selectin; sICAM: soluble intercellular adhesion molecule; SPM: specialized pro-resolving mediators of inflammation; sTM: soluble } \\
\text { hrombomodulin; sVCAM: soluble Vascular cell adhesion protein; T2D: type } 2 \text { diabetes mellitus; TGF- } \beta \text { : transforming growth factor-beta; TNF- } \alpha \text { : tumor necrosis factor alpha; tPA: tissue } \\
\text { lasminogen activator; TPAC: total plasma antioxidant capacity; VCAM: vascular cell adhesion protein; VLA: very late antigen; vWf: von Willebrand factor; WW: white wine. }\end{array}$} \\
\hline
\end{tabular}


Among inflammation parameters investigated, C-reactive protein (CRP) was one of the most considered, since it has been identified by several authors as a significant predictor of cardiovascular events [44]. Acute red wine intake (fasting or at meals) was not associated with significant C-reactive protein reduction, as observed by Cuervo et al. [28], and Retterstol et al. [29]. This could be due to different factors; among the others:

1. The duration of the study, which could be too short to observe a significant change in inflammatory parameters in healthy subjects having physiological CRP levels (0.11-0.55 mg/dL) [28]. The study by Marfella et al. [42], seemed to support this hypothesis. Indeed, T2D patients, with a myocardial infarction history, consuming $118 \mathrm{~mL}$ wine/day in the previous 12 years showed CRP levels significantly lower when compared to abstainers $(p<0.01)$ [42];

2. The amount of wine consumed (100-150 mL/day, $15 \mathrm{~g}$ ethanol) was lower when compared to studies where a CRP reduction was observed (>200 mL, $20 \mathrm{~g}$ ethanol) [36].

Fibrinogen and other factors involved in platelet aggregation (e.g., platelet-activating factor-PAF; von Willebrand factor-vWf; plasminogen activator inhibitor-PAI-I; plasminogen activator inhibitor/tissue plasminogen activator-PAI/tPA ratio) appear to be affected by both acute and regular intake of both red and white wine. The acute effect of ethanol on platelet aggregation is controversial, as both inhibition and stimulation effects have been reported $[45,46]$. In the studies described in this review, red wine, but not ethanol, water or white wine alone, reduced platelet aggregation within $3.5 \mathrm{~h}$, suggesting an additional positive effect of polyphenols of red wine. Two studies reported an additional effect on circulating endothelial adhesion molecules ICAM-1 and VCAM-1, after red wine consumption (160-280 mL/day) [36,43]. If confirmed, these effects could explain the reduced $\mathrm{vWf}$ levels observed in moderate wine diabetic consumers, since hyperglycemia stimulates platelet aggregation [43]. Taking into account the number of studies collected and the low number of trial participants, however, the effects of wine on aggregation has to be investigated in further well-designed studies.

As regards other inflammatory parameters, such as interleukins and their gene expression, some discrepancies have been observed in the literature. Schwarz et al. [37] and Sacanella et al. [34] observed a significant reduction of IL-6 levels and its expression, after acute or regular wine intake (4 weeks $200 \mathrm{~mL}$ red wine +4 weeks $200 \mathrm{~mL}$ white wine) in healthy subjects. On the other hand, no effects on IL-6 were found by Argyrou et al. [32] and Tousolis et al. [33] after acute consumption of wine. This result was confirmed by Williams et al. [38], who measured an IL-6 increase in patients with CAD (coronary artery disease). It is possible that in acute consumption, the alcohol-mediated oxidative stress in the liver may be involved in the cytokines production increase [47]; on the other hand, longer term wine consumption could enable the wine phenolic fraction to counteract this imbalance. In fact, according to in vitro studies, flavonoids in wine suppress the synthesis of proinflammatory cytokines and chemokines (such as TNF- $\alpha$, IL-1b, IL-6, IL-8, and MCP-1, von Willebrand plasma levels), mainly via NF-kB pathway modulation [45].

Neither regular ( $500 \mathrm{~mL} /$ day for 2 weeks) nor acute ( $200 \mathrm{~mL} /$ one dose) consumption of red wine were associated with a positive effect on inflammatory biomarkers associated with immunological responses such as neutrophils and monocytes phagocytic activity and $\mathrm{T}$ cell apoptosis in healthy subjects $[39,40]$, confirming that NF- $\mathrm{kB}$ is a possible mediator of the wine protective effects.

Table 4 summarizes, for each physiological system, the results of in vitro, animal, and human studies reviewed in this paper [12-16,18-24,28-30,32-34,37-43]. 
Table 4. Summary of in vitro, animal, and human studies reviewed.

\begin{tabular}{|c|c|c|c|c|}
\hline & Area & Wine Amount & Results & Ref. \\
\hline \multirow{5}{*}{ 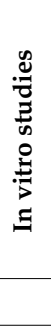 } & Cardiovascular & 1-25 $\mu \mathrm{mol} / \mathrm{L}$ GAE RW & $\begin{array}{l}\downarrow \text { endothelial adhesion } \\
\text { molecules }\end{array}$ & [14] \\
\hline & Intestinal (Caco2) & $8.51 \mu \mathrm{g} / \mathrm{mL}$ GAE RW & $\downarrow$ IL-6 & [15] \\
\hline & Intestinal (H29) & 100-600 $\mu \mathrm{g} / \mathrm{mL}$ GAE RW & $\downarrow \mathrm{IL}-8$ and $\downarrow \mathrm{COX} 2$ & {$[16,17]$} \\
\hline & $\begin{array}{l}\text { Intestinal } \\
\text { (Colon-derived CCD-18Co } \\
\text { myofibroblast cells) }\end{array}$ & 25-100 $\mu \mathrm{g} / \mathrm{mL}$ GAE RW & $\downarrow$ VCAM-1 & [18] \\
\hline & Area & Wine amount & Results & Ref. \\
\hline \multirow{6}{*}{ 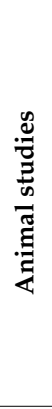 } & \multirow[b]{2}{*}{ Cardiovascular (rats) } & $\begin{array}{l}50 \mathrm{~mL} / \mathrm{kg} \mathrm{bw} \\
W W \text { for } 4 \text { weeks }\end{array}$ & $\begin{array}{l}\uparrow C D 44 \text { expression; } \\
\downarrow \text { MMP-9 expression }\end{array}$ & {$[22,23]$} \\
\hline & & $\begin{array}{l}35 \mathrm{~mL} / \mathrm{Kg} \text { bw } \\
\mathrm{RW} \text { for } 4 \text { weeks }\end{array}$ & $\begin{array}{l}\downarrow \text { adiponectin, } \downarrow \text { resistin, } \\
\downarrow \text { VCAM- } 1 \text { and } \downarrow \text { plasmatic } \\
\text { antioxidant activity }\end{array}$ & [26] \\
\hline & \multirow{2}{*}{ Gastric/Intestinal (mice) } & \multirow{2}{*}{$\begin{array}{l}250 \mathrm{~mL} / \mathrm{kg} \text { bw/day } \\
\mathrm{RW} 4 \text { days }\end{array}$} & $\downarrow$ epithelial gastric damage & [25] \\
\hline & & & $\downarrow \mathrm{MPO}$ levels & [24] \\
\hline & \multirow{2}{*}{ Inflammation (rats) } & $\begin{array}{l}28 \mathrm{~mL} / \mathrm{Kg} \mathrm{bw} \\
\text { DRW and DWW for } 15 \text { day }\end{array}$ & $\begin{array}{l}\downarrow \text { Oxidative stress (RW) } \\
\downarrow \text { MDA (RW and WW) }\end{array}$ & [20] \\
\hline & & $3.6 \mathrm{~mL} / \mathrm{Kg}$ bw RW 4 weeks & $\downarrow \mathrm{MDA}$ & [21] \\
\hline \multirow{10}{*}{ 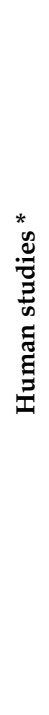 } & \multirow{5}{*}{ Cardiovascular (Healthy subjects) } & $1.4 \mathrm{~mL} / \mathrm{kg}$ bw RW 12 months & $\downarrow \mathrm{MDA}$ & [28] \\
\hline & & $2.1 \mathrm{~mL} / \mathrm{kg}$ bw RW 3 weeks & $\downarrow \mathrm{Fib}$ & [29] \\
\hline & & $\begin{array}{l}4 \mathrm{~mL} / \mathrm{kg} \text { bw day RW and } \mathrm{WW}, \\
\text { single dose }\end{array}$ & \multirow{2}{*}{$\begin{array}{l}\downarrow \text { PAF, } \downarrow \text { E-selectin }, \downarrow \text { ICAM, } \\
\downarrow \text { TNF- } \alpha, \downarrow \text { IL- } 6, \downarrow \text { IL- } 8, \downarrow \text { CRP }\end{array}$} & {$[30,32,33]$} \\
\hline & & $\begin{array}{l}2.9 \mathrm{~mL} / \mathrm{kg} \text { bw day } \mathrm{RW} \text { and } \mathrm{WW} \\
\text { for } 4 \text { weeks each }\end{array}$ & & [34] \\
\hline & & $\begin{array}{l}\text { RW aiming to reach } 0.075 \% \\
\text { blood alcohol in occasional } \\
\text { smokers }\end{array}$ & $\downarrow \mathrm{IL}-6, \downarrow \mathrm{TNF}-\alpha, \downarrow \mathrm{IL}-1 \mathrm{~b}$ & [37] \\
\hline & Cardiovascular (CAD patients) & $4 \mathrm{~mL} / \mathrm{kg} \mathrm{bw}$, single dose & $\uparrow \mathrm{IL}-6$ & [38] \\
\hline & \multirow{3}{*}{ Type 2 diabetes } & $\begin{array}{l}>0-<20 \mathrm{~g} / \text { day } \\
0-<2.9 \mathrm{~mL} / \mathrm{kg} \mathrm{bw}\end{array}$ & $\downarrow$ inflammatory parameters & [43] \\
\hline & & $\begin{array}{l}1.69 \mathrm{~mL} / \mathrm{kg} \text { bw RW for } 12 \\
\text { months }\end{array}$ & $\downarrow$ inflammatory parameters & [42] \\
\hline & & $\begin{array}{l}3.8 \mathrm{~mL} / \mathrm{kg} \mathrm{bw} \\
\mathrm{RW} \text { or DRW for } 4 \text { weeks each }\end{array}$ & No effects & [41] \\
\hline & Immune function & $\begin{array}{l}2.50 \mathrm{~mL} / \mathrm{kg} \text { bw RW single dose; } \\
7.14 \mathrm{~mL} / \mathrm{kg} \text { bw RW for } 2 \text { weeks }\end{array}$ & No effects & {$[39,40]$} \\
\hline
\end{tabular}

* To compare wine amount intake in human studies, a $70 \mathrm{~kg}$ average weigh was used. CD: clusters of differentiation; COX-2: cyclooxigenase-2; CRP: C-reactive protein; DRW: dealcoholized red wine; DWW: dealcoholized white wine; Fib: Fibrinogen; GAE: gallic acid equivalent; ICAM: intercellular adhesion molecule; IL: interleukin; MDA: malondyaldehide; MMP: matrix metallopeptidase; MPO: myeloperoxidase; PAF: platelet-activating factor; RW: red wine; TNF- $\alpha$ : tumor necrosis factor $\alpha$; VCAM: vascular cell adhesion protein; WW: white wine.

In in vitro models, wine extracts were generally used in an amount aimed to mimic the in vivo polyphenol concentrations observed in the colon [48]. The reduction of inflammatory cytokines (e.g., IL-6, IL-8, COX-2, and VCAM-1) was observed using red wine polyphenol concentrations in the range of $0.17-600 \mu \mathrm{g} / \mathrm{mL}$. These effects seem to be mediated by the inhibition of NF- $\mathrm{kB}$ DNA binding activity, while other pathways seem to be less involved (i.e., AP-1). According to the authors and previous studies [19] anthocyanins, which are among the most abundant compounds in RWEs, could be the main responsible for the biological effects observed, although the contribution of other polyphenols, including procyanidins, cannot be excluded. Moreover, coumaric acid, kaempferol, and resveratrol showed a lower concentration but a specific higher activity in reducing the inflammatory parameters.

In animal studies, MDA and 8-OHdG, markers of oxidative stress, were significantly reduced by wine. It should be noticed that in most studies, dealcoholized extracts were used, so that only the effect of wine polyphenols was evaluated. In gastric/intestinal areas, animal studies showed promising 
positive effects for wine (50-250 $\mathrm{mL} / \mathrm{kg}$ bw rats or mice) in reducing cytokine production and gastritis severity associated with $H$. pylori infection. This effect has to be confirmed, however, in human studies.

\section{Conclusions}

The purpose of this review was to collect and discuss the experimental approaches and the scientific evidences of in vitro and in vivo studies aimed to evaluate the relationship between wine consumption and inflammation. Even though moderate wine consumption has been associated with lower risk for cardiovascular diseases, a great heterogeneity characterizes the studies performed to establish a correlation among beneficial effects of wine consumption: wine typology, composition (when reported), biomarkers measured, length and amount of consumption, together with the use of appropriate controls make difficult a suitable comparison.

In humans, inflammatory parameters associated with platelet aggregation seem to be affected by moderate wine intake, while contradictory results were obtained for some inflammation biomarkers (e.g., CRP and IL-6). Conversely, no significant effects were measured in inflammatory responses associated with immune function. For this reason, further studies (including in vitro models), evaluating wine effects on biomarkers of immune response, should be designed. Integration of in vitro studies with animal and human trials could lead to a better wine effects evaluation and comprehension of the most plausible mechanisms of action.

Author Contributions: C.D.L. and P.R. evaluated the collected papers and wrote the manuscript; C.S. and M.D. revised the paper; F.C., S.B. and F.O. performed the first literature analysis.

Funding: This research received no external funding.

Acknowledgments: This research was supported by grants from MIUR Progetto Eccellenza.

Conflicts of Interest: The authors declare no conflict of interest.

\section{References}

1. Friedman, L.A.; Kimball, A.W. Coronary heart disease mortality and alcohol consumption in Framingham. Am. J. Epidemiol. 1986, 124, 481-489. [CrossRef] [PubMed]

2. Renaud, S.; de Lorgeril, M. Wine, alcohol, platelets, and the French paradox for coronary heart disease. Lancet 1992, 339, 1523-1526. [CrossRef]

3. Iestra, J.A.; Kromhout, D.; Van Der Schouw, Y.T.; Grobbee, D.E.; Boshuizen, H.C.; Van Staveren, W.A. Effect size estimates of lifestyle and dietary changes on all-cause mortality in coronary artery disease patients: A systematic review. Circulation 2005, 112, 924-934. [CrossRef] [PubMed]

4. Pavlidou, E.; Mantzorou, M.; Fasoulas, A.; Tryfonos, C.; Petridis, D.; Giaginis, C. Wine: An Aspiring Agent in Promoting Longevity and Preventing Chronic Diseases. Diseases 2018, 6, 73. [CrossRef] [PubMed]

5. Boban, M.; Stockley, C.; Teissedre, P.L.; Restani, P.; Fradera, U.; Stein-Hammer, C.; Ruf, J.C. Drinking pattern of wine and effects on human health: Why should we drink moderately and with meals? Food Funct. 2016, 7, 2937-2942. [CrossRef] [PubMed]

6. Dell'Agli, M.; Buscialà, A.; Bosisio, E. Vascular effects of wine polyphenols. Cardiovasc. Res. 2004, 63, 593-602. [CrossRef] [PubMed]

7. Stockley, C.; Teissedre, P.L.; Boban, M.; Di Lorenzo, C.; Restani, P. Bioavailability of wine-derived phenolic compounds in humans: A review. Food Funct. 2012, 3, 995-1007. [CrossRef] [PubMed]

8. Smoliga, J.M.; Baur, J.A.; Hausenblas, H.A. Resveratrol and health-A comprehensive review of human clinical trials. Mol. Nutr. Food Res. 2011, 55, 1129-1141. [CrossRef] [PubMed]

9. Pastor, R.F.; Restani, P.; Di Lorenzo, C.; Orgiu, F.; Teissedre, P.-L.; Stockley, C.; Ruf, J.C.; Quini, C.I.; Garcìa Tejedor, N.; Gargantini, R.; et al. Resveratrol, human health and winemaking perspectives. Crit. Rev. Food Sci. Nutr. 2017, 8398, 1-19. [CrossRef] [PubMed]

10. Boban, M.; Modun, D. Uric Acid and Antioxidant Effects of Wine. Croat. Med. J. 2010, 51, 16-22. [CrossRef] [PubMed]

11. Pawelec, G.; Goldeck, D.; Derhovanessian, E. Inflammation, ageing and chronic disease. Curr. Opin. Immunol. 2014, 29, 23-28. [CrossRef] [PubMed] 
12. Kunnumakkara, A.B.; Sailo, B.L.; Banik, K.; Harsha, C.; Prasad, S.; Gupta, S.C.; Bharti, A.C.; Aggarwal, B.B. Chronic diseases, inflammation, and spices: How are they linked? J. Transl. Med. 2018, 16, 1-25. [CrossRef] [PubMed]

13. Hunter, $\mathrm{P}$. The inflammation theory of disease. The growing realization that chronic inflammation is crucial in many diseases opens new avenues for treatment. EMBO Rep. 2012, 13, 968-970. [CrossRef] [PubMed]

14. Calabriso, N.; Scoditti, E.; Massaro, M.; Pellegrino, M.; Storelli, C.; Ingrosso, I.; Giovinazzo, G.; Carluccio, M.A. Multiple anti-inflammatory and anti-atherosclerotic properties of red wine polyphenolic extracts: Differential role of hydroxycinnamic acids, flavonols and stilbenes on endothelial inflammatory gene expression. Eur. J. Nutr. 2016, 55, 477-489. [CrossRef] [PubMed]

15. Nicod, N.; Chiva-Blanch, G.; Giordano, E.; Dávalos, A.; Parker, R.S.; Visioli, F. Green tea, cocoa, and red wine polyphenols moderately modulate intestinal inflammation and do not increase high-density lipoprotein (HDL) production. J. Agric. Food Chem. 2014, 62, 2228-2232. [CrossRef] [PubMed]

16. Nunes, C.; Ferreira, E.; Freitas, V.; Almeida, L.; Barbosa, R.M.; Laranjinha, J. Intestinal anti-inflammatory activity of red wine extract: Unveiling the mechanisms in colonic epithelial cells. Food Funct. 2013, 4, 373-383. [CrossRef] [PubMed]

17. Nunes, C.; Teixeira, N.; Serra, D.; Freitas, V.; Almeida, L.; Laranjinha, J. Red wine polyphenol extract efficiently protects intestinal epithelial cells from inflammation via opposite modulation of JAK/STAT and Nrf2 pathways. Toxicol. Res. (Camb.) 2015, 5, 53-65. [CrossRef] [PubMed]

18. Angel-Morales, G.; Noratto, G.; Mertens-Talcott, S. Red wine polyphenolics reduce the expression of inflammation markers in human colon-derived CCD-18Co myofibroblast cells: Potential role of microRNA-126. Food Funct. 2012, 3, 745-752. [CrossRef] [PubMed]

19. Singer, I.I.; Kawka, D.W.; Schloemann, S.; Tessner, T.; Riehl, T.; Stenson, W.F. Cyclooxygenase 2 is induced in colonic epithelial cells in inflammatory bowel disease. Gastroenterology 1998, 115, 297-306. [CrossRef]

20. López, D.; Pavelkova, M.; Gallova, L.; Simonetti, P.; Gardana, C.; Lojek, A.; Loaiza, R.; Mitjavila, M.T. Dealcoholized red and white wines decrease oxidative stress associated with inflammation in rats. Br. J. Nutr. 2007, 98, 611-619. [CrossRef] [PubMed]

21. Macedo, L.F.L.; Rogero, M.M.; Guimarães, J.P.; Granato, D.; Lobato, L.P.; Castro, I.A. Effect of red wines with different in vitro antioxidant activity on oxidative stress of high-fat diet rats. Food Chem. 2013, 137, 122-129. [CrossRef] [PubMed]

22. Režić-Mužinić, N.; Mastelić, A.; Benzon, B.; Markotić, A.; Mudnić, I.; Grković, I.; Grga, M.; Milat, A.M.; Ključević, N.; Boban, M. Expression of adhesion molecules on granulocytes and monocytes following myocardial infarction in rats drinking white wine. PLoS ONE 2018, 13, 1-11. [CrossRef] [PubMed]

23. Ključević, N.; Milat, A.M.; Grga, M.; Mudnić, I.; Boban, M.; Grković, I. White wine consumption influences inflammatory phase of repair following myocardial infarction in rats. J. Cardiovasc. Pharmacol. 2017, 70, 1. [CrossRef] [PubMed]

24. Li, R.; Kim, M.H.; Sandhu, A.K.; Gao, C.; Gu, L. Muscadine grape (Vitis rotundifolia) or wine phytochemicals reduce intestinal inflammation in mice with dextran sulfate sodium-induced colitis. J. Agric. Food Chem. 2017, 65, 769-776. [CrossRef] [PubMed]

25. Ruggiero, P.; Rossi, G.; Tombola, F.; Pancotto, L.; Lauretti, L.; Del Giudice, G.; Zoratti, M. Red wine and green tea reduce H pylori- or VacA-induced gastritis in a mouse model. World J. Gastroenterol. 2007, 13, 349-354. [CrossRef] [PubMed]

26. Vazquez-Prieto, M.A.; Renna, N.F.; Diez, E.R.; Cacciamani, V.; Lembo, C.; Miatello, R.M. Effect of red wine on adipocytokine expression and vascular alterations in fructose-fed rats. Am. J. Hypertens. 2011, 24, $234-240$. [CrossRef] [PubMed]

27. Boussenna, A.; Cholet, J.; Goncalves-Mendes, N.; Joubert-Zakeyh, J.; Fraisse, D.; Vasson, M.P.; Texier, O.; Felgines, C. Polyphenol-rich grape pomace extracts protect against dextran sulfate sodium-induced colitis in rats. J. Sci. Food Agric. 2016, 96, 1260-1268. [CrossRef] [PubMed]

28. Cuervo, A.; de los Reyes-Gavilán, C.G.; Ruas-Madiedo, P.; Lopez, P.; Suarez, A.; Gueimonde, M.; González, S. Red Wine Consumption Is Associated with Fecal Microbiota and Malondialdehyde in a Human Population. J. Am. Coll. Nutr. 2015, 34, 135-141. [CrossRef] [PubMed]

29. Retterstol, L.; Berge, K.E.; Braaten, Ø.; Eikvar, L.; Pedersen, T.R.; Sandvik, L. A daily glass of red wine: Does it affect markers of inflammation? Alcohol. Alcohol. 2005, 40, 102-105. [CrossRef] [PubMed] 
30. Xanthopoulou, M.N.; Kalathara, K.; Melachroinou, S.; Arampatzi-Menenakou, K.; Antonopoulou, S.; Yannakoulia, M.; Fragopoulou, E. Wine consumption reduced postprandial platelet sensitivity against platelet activating factor in healthy men. Eur. J. Nutr. 2017, 56, 1485-1492. [CrossRef] [PubMed]

31. Detopoulou, P.; Nomikos, T.; Fragopoulou, E.; Antonopoulou, S.; Kotroyiannis, I.; Vassiliadou, C.; Panagiotakos, D.B.; Chrysohoou, C.; Pitsavos, C.; Stefanadis, C. Platelet activating factor (PAF) and activity of its biosynthetic and catabolic enzymes in blood and leukocytes of male patients with newly diagnosed heart failure. Clin. Biochem. 2009, 42, 44-49. [CrossRef] [PubMed]

32. Argyrou, C.; Vlachogianni, I.; Stamatakis, G.; Demopoulos, C.A.; Antonopoulou, S.; Fragopoulou, E. Postprandial effects of wine consumption on Platelet Activating Factor metabolic enzymes. Prostaglandins Other Lipid Mediat. 2017, 130, 23-29. [CrossRef] [PubMed]

33. Tousoulis, D.; Ntarladimas, I.; Antoniades, C.; Vasiliadou, C.; Tentolouris, C.; Papageorgiou, N.; Latsios, G.; Stefanadis, C. Acute effects of different alcoholic beverages on vascular endothelium, inflammatory markers and thrombosis fibrinolysis system. Clin. Nutr. 2008, 27, 594-600. [CrossRef] [PubMed]

34. Sacanella, E.; Vazquez-Agell, M.; Mena, M.P.; Antunez, E.; Fernandez-Sola, J.; Nicolas, J.M.; Lamuela-Raventos, R.M.; Ros, E.; Estruch, R. Down-regulation of adhesion molecules and other inflammatory biomarkers after moderate wine consumption in healthy women: A randomized trial. Am. J. Clin. Nutr. 2007, 86, 1463-1469. [CrossRef] [PubMed]

35. Avellone, G.; Di Garbo, V.; Campisi, D.; De Simone, R.; Raneli, G.; Scaglione, R.; Licata, G. Effects of moderate Sicilian red wine consumption on inflammatory biomarkers of atherosclerosis. Eur. J. Clin. Nutr. 2006, 60, 41-47. [CrossRef] [PubMed]

36. Estruch, R.; Sacanella, E.; Badia, E.; Antúnez, E.; Nicolás, J.M.; Fernández-Solá, J.; Rotilio, D.; De Gaetano, G.; Rubin, E.; Urbano-Márquez, A. Different effects of red wine and gin consumption on inflammatory biomarkers of atherosclerosis: A prospective randomized crossover trial: Effects of wine on inflammatory markers. Atherosclerosis 2004, 175, 117-123. [CrossRef] [PubMed]

37. Schwarz, V.; Bachelier, K.; Schirmer, S.H.; Werner, C.; Laufs, U.; Böhm, M. Red Wine Prevents the Acute Negative Vascular Effects of Smoking. Am. J. Med. 2017, 130, 95-100. [CrossRef] [PubMed]

38. Williams, M.J.A.; Sutherland, W.H.F.; Whelan, A.P.; McCormick, M.P.; De Jong, S.A. Acute effect of drinking red and white wines on circulating levels of inflammation-sensitive molecules in men with coronary artery disease. Metabolism 2004, 53, 318-323. [CrossRef] [PubMed]

39. Ellinger, S.; Arendt, B.M.; Fimmers, R.; Stehle, P.; Spengler, U.; Goerlich, R. Bolus ingestion but not regular consumption of native or dealcoholized red wine modulates selected immunological functions of leukocytes in healthy volunteers. Ann. Nutr. Metab. 2008, 52, 288-295. [CrossRef] [PubMed]

40. Watzl, B.; Bub, A.; Pretzer, G.; Roser, S.; Barth, S.W.; Rechkemmer, G. Daily moderate amounts of red wine or alcohol have no effect on the immune system of healthy men. Eur. J. Clin. Nutr. 2004, 58, 40-45. [CrossRef] [PubMed]

41. Barden, A.; Shinde, S.; Phillips, M.; Beilin, L.; Mas, E.; Hodgson, J.M.; Puddey, I.; Mori, T.A. The effects of alcohol on plasma lipid mediators of inflammation resolution in patients with Type 2 diabetes mellitus. Prostaglandins Leukot. Essent. Fat. Acids 2018, 133, 29-34. [CrossRef] [PubMed]

42. Marfella, R.; Cacciapuoti, F.; Siniscalchi, M.; Sasso, F.C.; Marchese, F.; Cinone, F.; Musacchio, E.; Marfella, M.A.; Ruggiero, L.; Chiorazzo, G.; et al. Effect of moderate red wine intake on cardiac prognosis after recent acute myocardial infarction of subjects with Type 2 diabetes mellitus. Diabet. Med. 2006. [CrossRef] [PubMed]

43. Van Bussel, B.C.T.; Henry, R.M.A.; Schalkwijk, C.G.; Dekker, J.M.; Nijpels, G.; Feskens, E.J.M.; Stehouwer, C.D.A. Alcohol and red wine consumption, but not fruit, vegetables, fish or dairy products, are associated with less endothelial dysfunction and less low-grade inflammation: The Hoorn Study. Eur. J. Nutr. 2017, 1-11. [CrossRef] [PubMed]

44. Ridker, P.M.; Hennekens, C.H.; Buring, J.E.; Rifai, N.; Markers, C.P.; Inflammationthe, O.F.; Of, P.; Diseasewomen, C. C-reactive protein and other markers of inflammation in the prediction of cardiovascular disease in women. N. Engl. J. Med. 2000, 342, 836-843. [CrossRef] [PubMed]

45. Mikhailidis, D.P.; Jeremy, J.Y.; Barradas, M.A.; Green, N.; Dandona, P. Effect of ethanol on vascular prostacyclin (prostaglandin I2) synthesis, platelet aggregation, and platelet thromboxane release. BMJ 1983, 287, 1495. [CrossRef] [PubMed] 
46. Zhang, Q.H.; Das, K.; Siddiqui, S.; Myers, A.K. Effects of acute, moderate ethanol consumption on human platelet aggregation in platelet-rich plasma and whole blood. Alcohol. Clin. Exp. Res. 2000, 24, 528-534. [CrossRef] [PubMed]

47. Colantoni, A.; Duffner, L.A.; De Maria, N.; Fontanilla, C.V.; Messingham, K.A.; Van Thiel, D.H.; Kovacs, E.J. Dose-dependent effect of ethanol on hepatic oxidative stress and interleukin-6 production after burn injury in the mouse. Alcohol. Clin. Exp. Res 2000, 24, 1443-1448. [CrossRef] [PubMed]

48. De Beer, D.; Harbertson, J.F.; Kilmartin, P.A.; Roginsky, V.; Barsukova, T.; Adams, D.O.; Waterhouse, A.L. Phenolics: A comparison of diverse analytical methods. Am. J. Enol. Vitic. 2004, 55, 389-400. [CrossRef]

(C) 2018 by the authors. Licensee MDPI, Basel, Switzerland. This article is an open access article distributed under the terms and conditions of the Creative Commons Attribution (CC BY) license (http:/ / creativecommons.org/licenses/by/4.0/). 